\title{
Now an empty mudflat: past and present benthic abundances in the western Dutch Wadden Sea
}

\author{
Casper Kraan · Anne Dekinga $\cdot$ Theunis Piersma
}

Received: 3 June 2009 / Accepted: 28 March 2010 / Published online: 10 April 2010

(C) Springer-Verlag and AWI 2010

\begin{abstract}
The benthic fauna of two areas in the western Dutch Wadden Sea, Posthuiswad and Staart van Schieringhals, was described in 1930-1960 and again between 1996 and 2005. Here, we document the changes. Whereas both areas formerly had high densities of species that biogenically structured the intertidal mudflats such as mussels Mytilus edulis and cockles Cerastoderma edule, by 1996 they had shown a tenfold decrease in the densities of molluscs, with no recovery till 2005. Although the number of species of polychaetes and crustaceans may not have changed much, their relative abundance did. Nowadays, more polychaete species are common than before. We briefly discuss whether the changes in benthic community composition could be due to industrial fishery practices or eutrophication effects.
\end{abstract}

Keywords Macrozoobenthos $\cdot$ Intertidal $\cdot$ Historical richness · Human impact · Dutch Wadden Sea

\section{Introduction}

Many mammals, turtles, and fish species of the world's oceans are in dire straits due to overexploitation (Jackson

Communicated by Karsten Reise.

C. Kraan $(\varangle) \cdot$ A. Dekinga $\cdot$ T. Piersma

NIOZ Royal Netherlands Institute for Sea Research,

P.O. Box 59, 1790 AB Den Burg, Texel, The Netherlands

e-mail: Casper.Kraan@nioz.nl

T. Piersma

Animal Ecology Group,

Centre for Ecological and Evolutionary Studies (CEES),

University of Groningen, P.O. Box 14,

9750 AA Haren, The Netherlands et al. 2001; Ellis 2003; Pauly and Maclean 2003). However worrying that is, inhabitants of the shallow parts of the oceans, areas exposed during low tide ("wadden"), suffered the same fate. In the last century, the European Wadden Sea lost structuring organisms like Sabellaria-reefs, inter- and subtidal Zostera meadows, and Ostrea edulis beds, due to overexploitation, diseases, and destruction (Reise 1982; Riesen and Reise 1982; Airoldi and Beck 2007; van Katwijk et al. 2009). The major difference between the open oceans and the intertidal flats is that the former had a greater share of attention, such that there is a general appreciation of their historical richness (e.g. Ellis 2003; Pauly and Maclean 2003). For a shallow area like the Wadden Sea, such synthesis, and the awareness that follows from it, is much more limited (but see Reise et al. 1989; Jensen 1992; Piersma 2006).

In the German and Danish parts of the Wadden Sea, there is a tradition of retrospective benthic analysis, that is comparing benthic biota from samples collected in the first half of the twentieth century (e.g. Thamdrup 1935; Linke 1939) with data from the same areas collected more recently (Riesen and Reise 1982; Reise et al. 1989, 2008; Jensen 1992). The aim of these studies is to show the proor regression an area has made over time, where the older benthic samples are treated as a baseline against which "change" is measured (Reise et al. 1989). The idea is that these data from the first half of the twentieth century represent a situation before the onset of, for example, increased eutrophication (Perus and Bonsdorff 2004), increased human disturbance (Riesen and Reise 1982), or intensified erosion (Reise et al. 1989).

For the Dutch part of the Wadden Sea, apart from assessments of extinctions and human exploitation of species (Wolff 2000, 2005), such kinds of historical reviews are not available, despite the fact that long-term benthic sampling 
programs have been carried out continuously since the 1970s (e.g. Beukema 1982; Zwarts and Wanink 1993; Essink et al. 1998). This is probably related to a mismatch between the geographical locations of these monitoring programmes at Balgzand (Beukema 1982) and coastal Groningen (Essink and Beukema 1986; Zwarts and Wanink 1993), and the locations of historical benthic studies in other parts of the western Wadden Sea (van der Baan et al. 1958; Kristensen 1957; but see Kuenen 1942). However, a "recent" (since 1996) benthic sampling programme, designed to monitor food for benthivorous shorebirds like red knots (Calidris canutus) and bar-tailed godwits (Limosa lapponica), covers most of the intertidal area in the western Dutch Wadden Sea (Piersma et al. 1993; van Gils et al. 2006b; Kraan et al. 2007, 2009), thereby offering a possibility for comparisons that we exploit here.

The aim of this study is to compare macrobenthic communities of two intertidal areas just south of Vlieland, i.e. Posthuiswad and Staart van Schieringhals (Fig. 1), in the 1930-1950s and from 1996 to 2005. These areas were well known for their richness of benthos, e.g. cockles Cerastoderma edule and mussels Mytilus edulis (Kreger 1940; Verwey 1952; Kristensen 1957), whereas nowadays Staart van Schieringhals in particular is nearly devoid of benthic life (pers. obs.). Since understanding the current state of an area may best be enhanced by reflection against a historical background (Riesen and Reise 1982; Reise 1995; Jackson et al. 2001), we not only focus on recent changes but also try to paint the former richness of these areas, i.e. a benthic baseline.

\section{Study areas and methods}

In July-September 1996-2005, we collected benthic samples at Posthuiswad and Staart van Schieringhals (Fig. 1). This was done over a pre-determined 250-m grid (Fig. 1), on foot during low tide or by boat otherwise. To locate sampling sites, we used hand-held GPS (Garmin 12 and 45; Garmin Corporation, Lenexa, Kansas, USA), where subsequently a core $\left(1 / 56 \mathrm{~m}^{2}\right)$ to a depth of $20-25 \mathrm{~cm}$ was taken. After sieving over a 1-mm mesh, all fauna were counted and recorded. Crustaceans and molluscs were collected in plastic bags and stored at $-20^{\circ} \mathrm{C}$ for later analyses in the laboratory (see Piersma et al. 1993; Kraan et al. 2007; van Gils et al. 2006a, b, 2009). Additionally, within each $\mathrm{km}^{2}$, a sediment sample was collected (Fig. 1) and analysed with a LS Coulter Counter (Zwarts et al. 2003; Bocher et al. 2007). Based on the descriptions and maps given by Kristensen (1957) and van der Baan et al. (1958), we matched the geographical extent of both areas as close as possible to theirs (Fig. 1). For Staart van Schieringhals, we validated our extent by comparing the positioning of the buoy closest to this area (IN1) in 1910 (Hoek 1911) with a recent map. This buoy still resided at its original location, which indicated that our placing of Staart van Schieringhals matched the historical one.

Although exact sampling locations are not given by van der Baan et al. (1958), their detailed portrayal of the sampling sites at Posthuiswad (sampled during the summer of 1956) made a similar division in zones possible by clustering sampling stations (Fig. 1). These zones were as follows:
Fig. 1 Study areas: Posthuiswad and Staart van Schieringhals. Both benthic (dot) and sediment (triangle) sampling locations are shown. Numbers 1-7 show the different zones (see "Study areas and methods" and Table 1). Light grey areas indicate mudflats exposed during low water at spring tides, white areas indicate water, and land is represented by the darkest grey areas. Square inside the small map of the Netherlands shows the location within the Dutch Wadden Sea

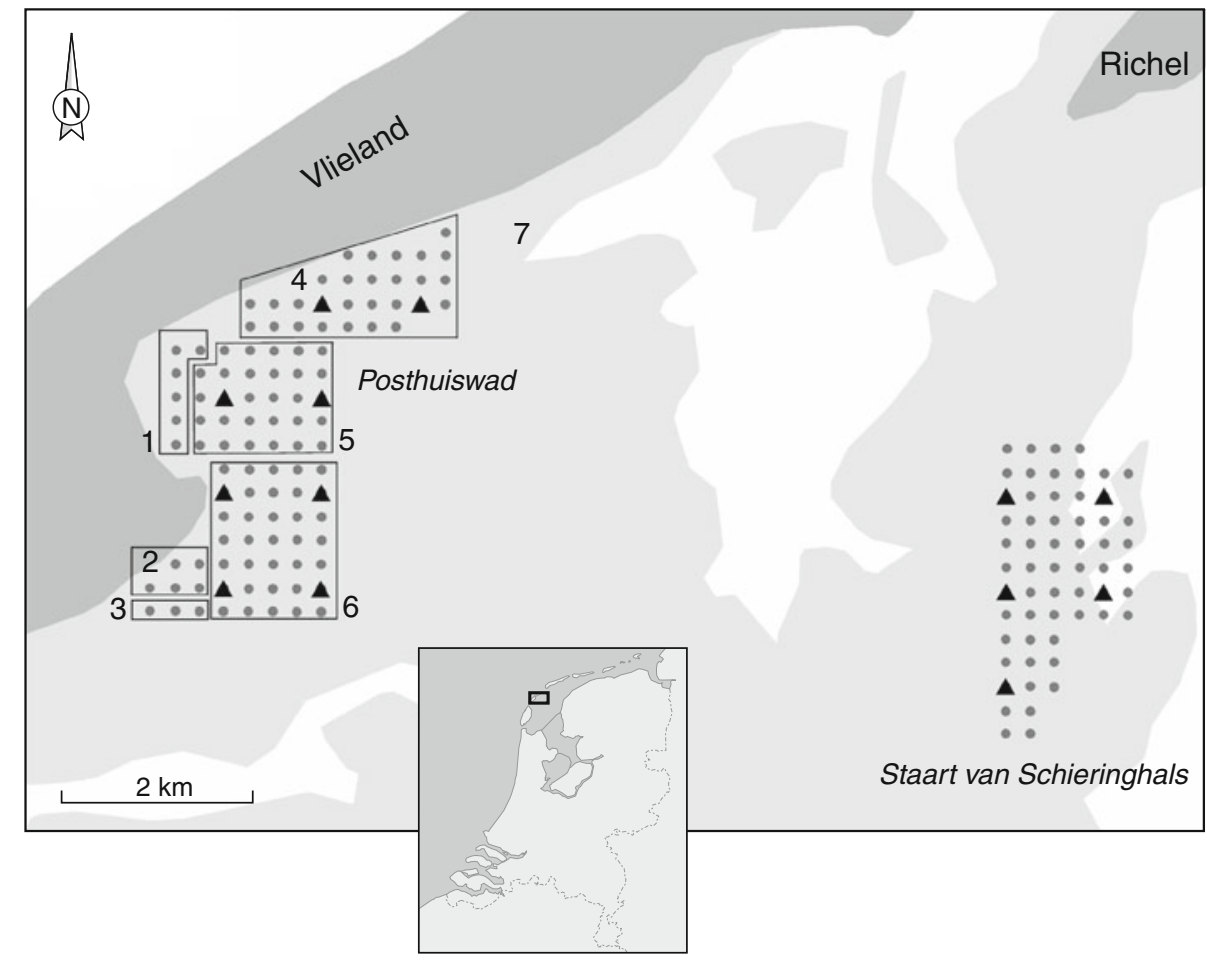


(1) border between salt marsh and mudflat, i.e. "Schor", (2) Vliehors high intertidal, (3) Vliehors low intertidal, (4) coast near the island, (5) Posthuiswad high intertidal, and (6) Posthuiswad low intertidal. They also recorded densities of macrofauna just opposite the gully (7). Van der Baan et al. (1958), while sampling to a depth of $30-40 \mathrm{~cm}$ with a standardized core and small-meshed sieve, focussed on common species only (C. Swennen, pers. comm.). Thus, species not dealt with were not necessarily absent but were uncommon or rare. We could, however, compare average densities per zone for the species that they recorded and their present occurrence in those same zones.

The historical data presented by Kreger (1940) and Kristensen (1957) of the Staart van Schieringhals focussed on cockles and mussels only and gave information on sediment characteristics. Since we suspected that, unlike the early studies of Posthuiswad, only areas with high abundances were sampled, we gave mean densities and maximum observed abundances during summer 1996-2005. Kreger (1940) dug up all sediment within a square frame and Kristensen (1957) dug up $20 \mathrm{dm}^{2}$ to a depth of $3 \mathrm{~cm}$. Both used a 1-mm sieve to collect and count cockles.

Based on Zwarts et al. (2003), who digitalized all sediment data from the 1950s-2002 within the Dutch Wadden Sea and standardized methods to allow comparisons, mud fraction values ( $\%$ of the sample with a grain-size $<16 \mu \mathrm{m}$ ) at Posthuiswad were on average 3-8\% from 1950 to 1955. Based on samples from the period 1996-2005, median grain-size was $190 \mu \mathrm{m}$ and the mud fraction $5 \%$.

At the Staart van Schieringhals, the median grain-size, based on samples collected between 1932 and 1955 (Postma 1957), was on average $100 \mu \mathrm{m}$. Kreger (1940), who sampled the area in 1937, mentioned the sediment as being "very fine sand" with a median grain-size of $106 \mu \mathrm{m}$. Kristensen (1957), using samples from 1948 (but from the same data-set as Postma) reported median grain-sizes ranging between 87 and $104 \mu \mathrm{m}$. Zwarts et al. (2003) estimated a mud fraction for 1950-1955 between 1 and 3\%. The average median grain-size in 1996-2005 was $144 \mu \mathrm{m}$ with a mud fraction of $3 \%$. From the limited amount of information, it appeared that the median grain-size of Staart van Schieringhals was coarser in 1996-2005 than it was in 1932-1955 (see also Piersma et al. 2001), while for both areas the mud fraction has not changed.

\section{Results}

\section{Posthuiswad}

The intensive sampling south of Vlieland by van der Baan et al. (1958) resulted in a detailed description of the zoned abundances of common species (Table 1). Corophium volutator and Hydrobia ulvae occurred in high densities throughout the area (Table 1). In 1996-2005, H. ulvae and C. volutator still were common (Table 1). A species that thrived in zone 1 in 1996-2005 was Abra tenuis, which was rare before. Zone 2 transformed from a mollusc-rich area into an area with almost no shellfish. Instead, the polychaetes Nereis diversicolor and Scoloplos armiger were abundant in 1996-2005, as was Bathyporeia sp. In 1996-2005, zone 3 was characterized by high densities of $S$. armiger (Table 1), but historically Heteromastus filiformis was the dominant polychaete. Formerly, Zostera marina was also present in this zone (van der Baan et al. 1958). Closest to the coast, in zone 4, polychaetes shifted markedly in relative abundance between 1956 and 1996-2005. In the 1950s, Eteone longa, $H$. filiformis, and S. armiger were the main species; in 1996-2005, these were H. filiformis, Lanice conchilega, and $N$. diversicolor, respectively. The high intertidal part of Posthuiswad (zone 5) used to show high densities of crustaceans (see Table 1), but in 1996-2005 densities were much lower. The polychaetes diversified (Table 1), with more species occurring in low abundances in 1996-2005. An area (Posthuiswad low intertidal) dominated by $C$. volutator, $H$. ulvae, and $H$. filiformis in the past, in 1996-2005, showed high densities of Bathyporeia sp., but many other species also occurred in low densities. It was the most biodiverse zone (Table 1).

In 1939, Kreger (1940) visited a number of large cockle beds just south of Vlieland, $1 \mathrm{~km}$ off the coast. He encountered a maximum density of 1,100 adult cockles per $\mathrm{m}^{2}$, while spat (i.e. "young-of-the-year") was present with 2,500 individuals per $\mathrm{m}^{2}$. Cockles were so dense here that their shells dented during growth (Fig. 18 in Kreger 1940). Mussel spat was abundant over much of the area. When van der Baan et al. (1958) visited presumably this area in 1956, they failed to find cockle beds (Table 1), probably due to three severe winters prior to 1956 (van der Baan et al. 1958). The next year (1957), cockle beds were present again.

\section{Staart van Schieringhals}

For the Staart van Schieringhals area, from the low water line onto higher parts of the mudflat, Kreger (1940) described the following for September 1937: "The number of cockles was small up to $240 \mathrm{~m}$ from the low water line of the Inschot. At $300 \mathrm{~m}$ from this line it increased to $100 \mathrm{per}$ $\mathrm{m}^{2}$, to become nearly 1,000 at 360, and 2,160 at $420 \mathrm{~m}$, finally to fall to 1,800 per $\mathrm{m}^{2}$ at $480 \mathrm{~m}$ from the water's edge". Kreger (1940) nicely visualized this by stating: "Where cockles were lying densest, the bottom seemed paved". Also there were beds of M. edulis (see Fig. 16 in Kreger 1940), as well as another large cockle bed a little bit further south. The highest cockle densities occurred higher 


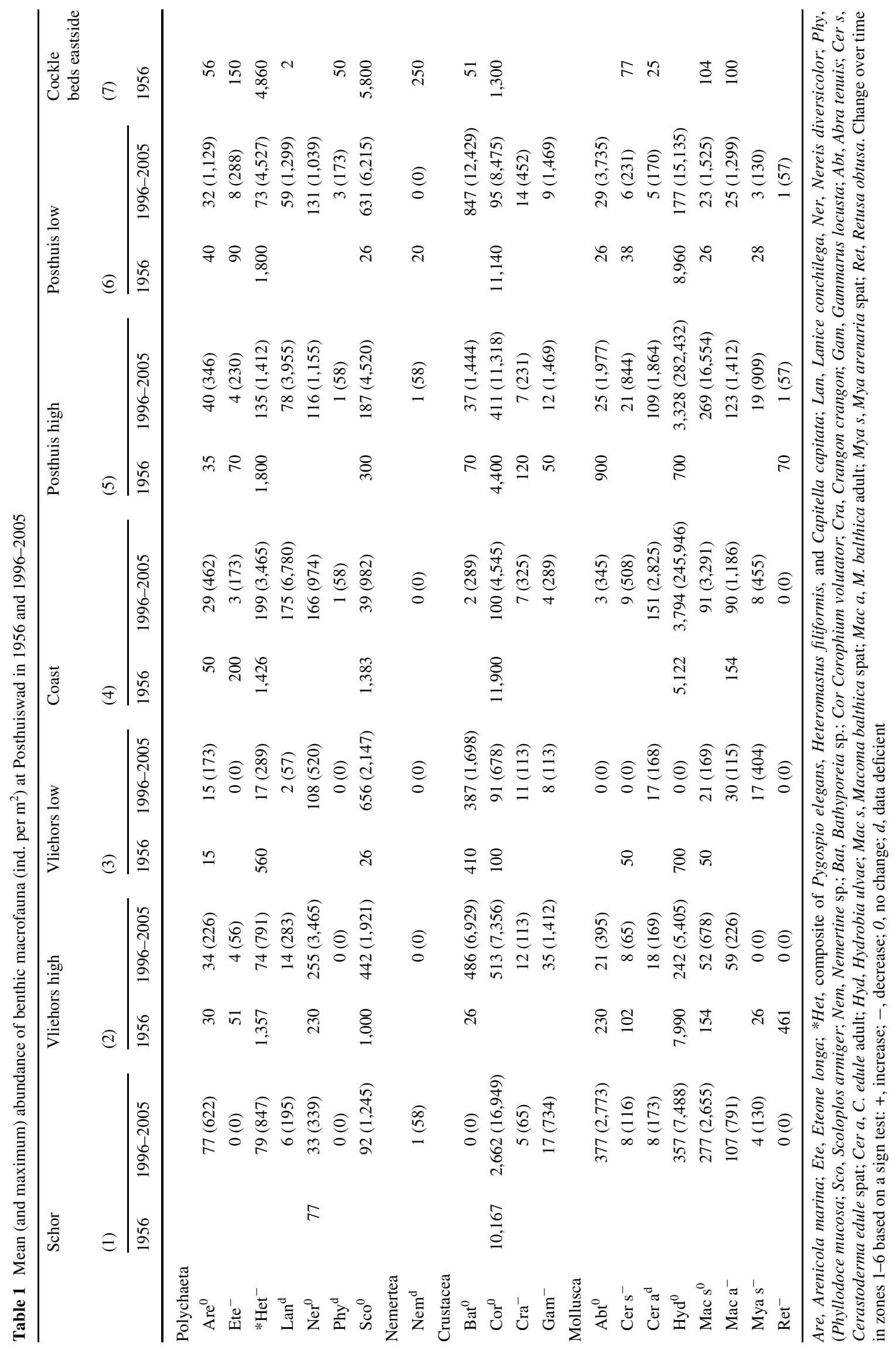


on the mudflat, where also the finest sands were present. At his next visit in summer 1939, both cockle beds were all but completely turned into large mussel beds with an elevation of 75-100 cm (Kreger 1940). Historical records of mussel beds in this area date back at least to 1856 when Allan (cited in Hoek 1911) noted that substantial mussel beds were present at the Waardgronden (which includes Staart van Schieringhals), but that there was a lack of manpower to harvest them.

In 1947, after 8 years Kreger (1940), a density of 170 cockles per $\mathrm{m}^{2}$ was estimated for the northern part of Staart van Schieringhals and for the southern part 655 cockles per $\mathrm{m}^{2}$ (Kristensen 1957). These abundances most likely refer to spat only, since after the severe winter of 1946-1947, cockles were almost exterminated from the intertidal mudflats (Kristensen 1957). Using two different sets of sampling stations (locations not given), Kristensen (1957) here also estimated densities of cockle spat, i.e. 101 and 738 individuals per $\mathrm{m}^{2}$. In summer 1948 , the cockle densities (adults and spat) varied from 30 (westward slope) to 395 per $\mathrm{m}^{2}$ on the eastward slope of Staart van Schieringhals (Kristensen 1957). The same locations held 180 and 555 cockles per $\mathrm{m}^{2}$ in July 1949 (Kristensen 1957).

During summer 1996-2005, we encountered a mean density of just 0.6 adult cockles per $\mathrm{m}^{2}$ and 0.1 mussels per $\mathrm{m}^{2}$. In this 10 -year period, the highest encountered density at any sampling location for both species was 58 individuals per $\mathrm{m}^{2}$.

\section{General pattern}

The general pattern emerging from these comparisons was a general decrease in molluscs, as well as a reduction in the crustaceans (Table 1). Polychaetes also changed; in 1996-2005, there was no particular species that really dominated, but several species commonly occurred (Table 1). This can be illustrated by plotting the densities of species recorded in 1956 at Posthuiswad against those same species in 1996-2005 (Fig. 2a-c). A two-tailed sign test confirmed that polychaetes as a group remained stable $(P \geq 0.05)$, whereas crustaceans and molluscs generally declined $(P \leq 0.05)$. Most observations were below the line that marked equal densities (Fig. 2a-c). Above the line were, for example, $S$. armiger at Vliehors low intertidal (Fig. 2a), Bathyporiea sp. (Vliehors high intertidal) in one zone (Fig. 2b), and Hydrobia ulvae at Posthuiswad high intertidal (Fig. 2c).

Trends over time, from 1956 to 2005 (Fig. 3), showed that molluscs and crustaceans decreased, while polychaetes remained "stable" (Fig. 3). Note that $H$. ulvae was excluded as they would obscure the trends. For example, in 1997, their mean density was enormous $\left(13,484\right.$ ind. per $\left.\mathrm{m}^{2}\right)$, whereas in 2003 and 2004, they were absent. (a) 1000
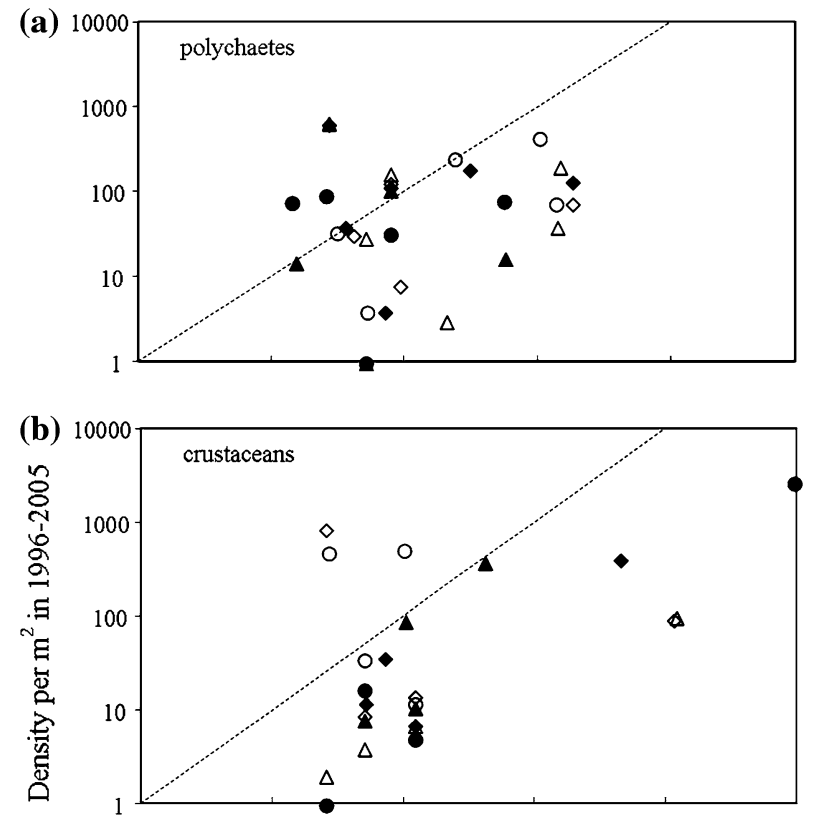

(c)

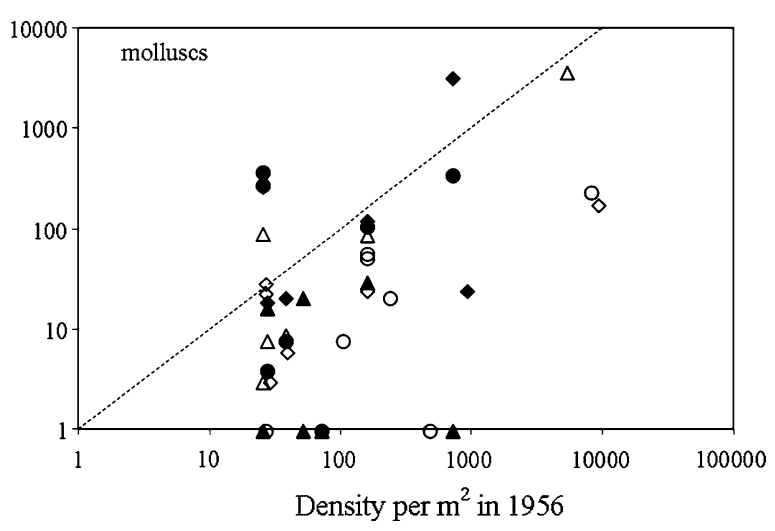

Fig. 2 Benthic abundances in 1956 and 1996-2005 of a polychaetes, b crustaceans, and c molluscs (both axes are log-scaled). The line marks equal abundances in 1956 and 1996-2005. Zones (see Table 1) are: 1 (filled circle), 2 (open circle), 3 (filled triangle), 4 (open triangle), 5 (filled diamond), 6 (open diamond)

\section{Discussion}

The first hurdle in retrospective analyses is finding ways in which different historical data-sets can be compared in unbiased ways. Usually, the documentation of historical data is brief and does not contain many methodological details. This means that a conservative approach has to be taken towards using these data-sets (Reise et al. 1989). For example, van der Baan et al. (1958) only gave densities of common species, which confined the comparisons to exact these same species. Kreger (1940) did not state sampling depth, but then he only focussed on $C$. edule and M. edulis, which both are living close to or on the surface (e.g. Smidt 1951; Verwey 1952). This, therefore, imposes no limitations. 


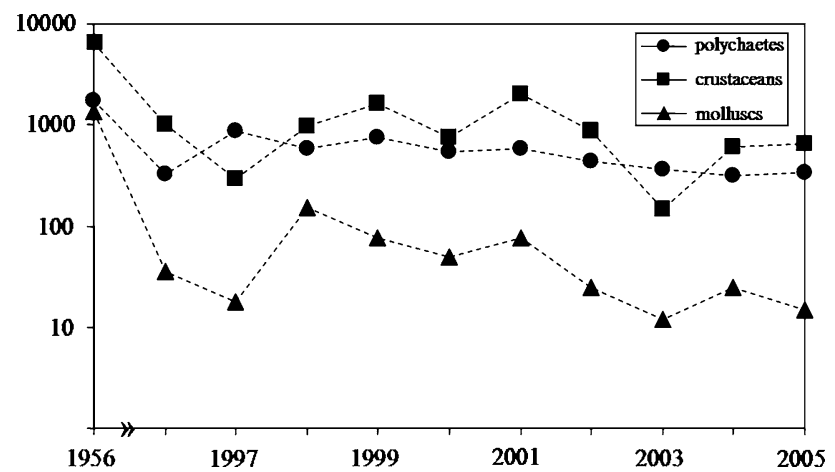

Fig. 3 Long- (1950s vs. ca. 2000) and short-term (1996-2005) trends presented as arithmetic means across zones of equal weighting, at Posthuiswad of polychaetes, crustaceans, and molluscs, respectively. H. ulvae was excluded from molluscs (see Table 1 for densities and "Results" for explanation). The groups are determined according to Table 1. That is, for each zone the species occurring in 1956 and those same species in 1996-2005 were used. Note the time-step on the $x$-axis, and the $\log$-scaled $y$-axis

Within the limits set by the historical data, it is clear that benthic communities of the two intertidal areas have become much poorer over the last half century. Staart van Schieringhals lost its large cockle and mussel beds, while at Posthuiswad both molluscs and crustaceans decreased, although polychaetes diversified (Table 1; Figs. 2, 3). It appears that smaller bodied macrozoobenthic species have been flourishing recently, whereas many larger bodied, long-lived species all but disappeared. As documented for other parts of the Wadden Sea, polychaetes are taking over (sensu Reise 1982; Beukema 1991; Lotze et al. 2005). This impression, however, is created by the large decrease in molluscs and crustaceans and not so much by an increase in polychaetes (Fig. 3).

The observed changes are likely to reflect a whole array of factors that need to be assessed within a pluralistic framework (Reise 1995; Scheffer et al. 2005). Nonetheless, we believe that two factors, eutrophication and the mechanical harvesting of shellfish, warrant discussion (see also Beukema and Cadée 1997; Piersma et al. 2001; van Raaphorst and de Jonge 2004; van Gils et al. 2006a; Kraan et al. 2007). Nutrient levels rapidly increased since the 1950s (de Jonge et al. 1993; van Raaphorst and de Jonge 2004) and in parallel the biomass and abundance of macrozoobenthos more than doubled (Beukema 1991; Beukema and Cadée 1997). The general consensus at the time was that intertidal benthos had been food limited up to that point (Beukema 1991; Beukema and Cadée 1997; Beukema et al. 2002). However, nutrient loadings decreased since the 1990s (Cadée and Hegeman 2002; van Beusekom 2005), and unexpectedly, total biomass still continued to increase (Dekker and Waasdorp 2007; Kuipers and van Noort 2008). Moreover, large and persistent mussel beds, oyster reefs and cockle banks formerly existed in the western Dutch
Wadden Sea, including our study areas, prior to increased nutrient levels (Hoek 1911; Kreger 1940; Verwey 1952; Kristensen 1957; van der Baan et al. 1958). If, however, nutrients limited the development of new mussel and cockle beds in the western Dutch Wadden Sea, why did they not profit from eutrophication when food was no longer limiting? In the German, and possibly the Danish Wadden Sea, for example, mussel beds increased under mild eutrophication (Reise et al. 1989; Jensen 1992).

Commercial harvesting of mussels and cockles in the western Dutch Wadden Sea dates back to at least 1884, a year when $2,068 \mathrm{~kg}$ of cockles were landed (Hoek 1911), and 1870 when the export of mussels to Belgium and England started, as well as a fishery for mussel spat (Hoek 1911; Dijkema 1997). In 1949, already 15 million $\mathrm{kg}$ of mussels were collected, which was an estimated one-third of the total biomass present (Verwey 1952). After 1970, cockle-fisheries developed from a small-scale fishery to an industry with 24 ships actively dredging for cockles with suction dredges (Dijkema 1997). Since that time, both the Staart van Schieringhals and Posthuiswad have been dredged on several occasions (Zwarts et al. 2003; van Gils et al. 2006a; Kraan et al. 2007), until mechanical cockledredging was outlawed in 2003 (Kraan et al. 2007; Swart and van Andel 2008). In 1990, nearly all intertidal mussels and cockles were harvested (Beukema and Cadée 1996; Beukema et al. 1998). Following this, in 1993, catches were regulated and some areas were closed from fisheries (Smit et al. 1998; Zwarts et al. 2003), but intertidal mussel beds and cockle banks never recovered in the areas open to fisheries (Smit et al. 1998; Herlyn and Millat 2000). Furthermore, in some closed areas like Posthuiswad, mussels have not re-established either (Piersma et al. 2001; Kraan et al. 2007; this paper). Note that hand-harvesting of cockles is still allowed in these areas. Our work has suggested that mechanical dredging has changed sediment characteristics (e.g. grain-size, but other characteristics as well) and negatively affected recruitment (Piersma et al. 1993, 2001; van Gils et al. 2006a).

Currently, the Wadden Sea may rank among the more degraded coastal seas worldwide (Lotze et al. 2006), mostly due to habitat destruction and overexploitation (Wolff 2000, 2005; Lotze et al. 2005, 2006). So far, there are few signs of recovery, which may imply that the longterm multiple impacts have reduced the system's resilience (Piersma et al. 2001; Lotze et al. 2006). Attempts since 1991 to restore low intertidal Zostera marina beds in the western Dutch Wadden Sea have failed (van Katwijk et al. 2009), M. balthica numbers continue a decline (van Gils et al. 2009), and intertidal mussel beds have not returned (Kraan et al. 2007; this study). This means that the area currently is in a state far from its historical baseline (Lotze et al. 2006). If the western Dutch Wadden Sea has been 
moved to another alternative stable state (sensu Scheffer et al. 2001; Scheffer and Carpenter 2003) over the last half century, what is necessary for its former richness to be restored?

Acknowledgments During most of the fieldwork, we were based on the Royal NIOZ-research vessel RV Navicula, and we thank Kees van de Star, Tony van der Vis, Johan Tuntelder, and Hein de Vries for their help. A large number of volunteers and students contributed to the collection of the field data. Wim J. Wolff and editor Karsten Reise gave valuable feedback on previous versions.

\section{References}

Airoldi L, Beck MW (2007) Loss, status and trends for coastal marine habitats of Europe. Oceanogr Mar Biol Ann Rev 45:345-405

Beukema JJ (1982) Annual variation in reproductive success and biomass of the major macrozoobenthic species living in a tidal flat area of the Wadden Sea. Neth J Sea Res 16:37-45

Beukema JJ (1991) Changes in composition of bottom fauna of a tidal-flat area during a period of mild eutrophication. Mar Biol 48:111-125

Beukema JJ, Cadée GC (1996) Consequences of the sudden removal of nearly all mussels and cockles from the Dutch Wadden Sea. Mar Ecol 17:279-289

Beukema JJ, Cadée GC (1997) Local differences in macrozoobenthic response to enhanced food supply caused by mild eutrophication in a Wadden Sea area: food is only locally a limiting factor. Limnol Oceanogr 42:1424-1435

Beukema JJ, Cadée GC, Dekker R (1998) How two large-scale "experiments" illustrate the importance of enrichment and fishery for the functioning of the Wadden Sea ecosystem. Senckenb Marit 29:37-44

Beukema JJ, Cadée GC, Dekker R (2002) Zoobenthic biomass limited by phytoplankton abundance: evidence from parallel changes in two long-term data series in the Wadden Sea. J Sea Res 48:111125

Bocher P, Piersma T, Dekinga A, Kraan C, Yates MG, Guyot T, Folmer EO, Radenac G (2007) Site- and species-specific distribution patterns of molluscs at five intertidal soft-sediment areas in northwest Europe during a single winter. Mar Biol 151:577-594

Cadée GC, Hegeman J (2002) Phytoplankton in the Marsdiep at the end of the 20th century; 30 years monitoring biomass, primary production, and Phaeocystis blooms. J Sea Res 48:97-110

de Jonge VN, Essink K, Boddeke R (1993) The Dutch Wadden Sea: a changed ecosystem. Hydrobiologia 265:45-71

Dekker R, Waasdorp D (2007) Het macrozoobenthos op twaalf raaien in de Waddenzee en de Eems-Dollard in 2006. Royal Neth Inst Sea Res- NIOZ-Rapport 2007-1, 60 pp

Dijkema R (1997) Molluscan fisheries and culture in the Netherlands. Technical Report NMFS 129. US Department of Commerce, Washington, $21 \mathrm{pp}$

Ellis R (2003) The empty ocean. Island Press/Shearwater Books, 368 pp

Essink K, Beukema JJ (1986) Long-term changes in intertidal flat macrozoobenthos as an indicator of stress by organic pollution. Hydrobiologia 142:209-215

Essink K, Eppinga J, Dekker R (1998) Long-term changes (19771994) in intertidal macrozoobenthos of the Dollard (Ems estuary) and the effects of introduction of the North American spionid polychaete Marenzelleria cf. wireni. Senckenb Marit 28:211-225

Herlyn M, Millat G (2000) Decline of the intertidal blue mussel (Mytilus edulis) stock at the coast of Lower Saxony (Wadden Sea) and influence of mussel fishery on the development of young mussel beds. Hydrobiologia 426:203-210

Hoek PPC (1911) Rapport over schelpdierenvisscherij en schelpdierenteelt in de Noordelijke Zuiderzee. Extra bijlage Verslag van den Staat der Nederlansche zeevisscherijen over 1910. 's Gravenhage, pp 1-163

Jackson JBC, Kirby MX, Berger WH, Bjorndal KA, Botsford LW, Bourque BJ, Bradburry RH, Cooke R, Erlandson J, Estes JA, Hughes TP, Kidwell S, Lange CB, Lenihan HS, Pandolfi JM, Peterson CH, Steneck RS, Tegner MJ, Warner RR (2001) Historical overfishing and the recent collapse of coastal systems. Science 293:629-638

Jensen KT (1992) Macrozoobenthos on an intertidal mudflat in the Danish Wadden Sea: comparisons of surveys made in the 1930s, 1940s and 1980s. Helgol Meeresunters 46:363-376

Kraan C, Piersma T, Dekinga A, Koolhaas A, van der Meer J (2007) Dredging for edible cockles Cerastoderma edule on intertidal flats: short-term consequences of fishermen's patch-choice decisions for target and non-target benthic fauna. ICES J Mar Sci 64:1735-1742

Kraan C, van Gils JA, Spaans B, Dekinga A, Bijleveld AI, Van Roomen M, Kleefstra R, Piersma T (2009) Landscape-scale experiment demonstrates that Wadden Sea intertidal flats are used to capacity by molluscivore migrant shorebirds. J Anim Ecol $78: 1259-1268$

Kreger D (1940) On the ecology of Cardium edule L. Arch Neerl Zool 4:157-200

Kristensen I (1957) Differences in density and growth in a cockle population in the Dutch Wadden Sea. Arch Neerl Zool 12:351-453

Kuenen DJ (1942) On the distribution of mussels on the intertidal sand flats near Den Helder. Arch Neerl Zool 6:117-160

Kuipers BR, van Noort GJ (2008) Towards a natural Wadden Sea? J Sea Res 60:44-53

Linke O (1939) Die biota des Jadebusenwattes. Helgol Wiss Meeresunters 1:201-348

Lotze HK, Reise K, Worm B, van Beusekom J, Busch M, Ehlers A, Heinrich D, Hoffmann C, Holm P, Jensen C, Knottnerus OS, Langhanki N, Prummel W, Vollmer M, Wolff WJ (2005) Human transformations of the Wadden Sea ecosystem through time: a synthesis. Helgol Mar Res 59:84-95

Lotze HK, Lenihan HS, Bourque BJ, Bradbury RH, Cooke RG, Kay MC, Kidwell SM, Kirby MX, Peterson CH, Jackson JBC (2006) Depletion, degradation, and recovery potential of estuaries and coastal seas. Science 312:1806-1809

Pauly D, Maclean J (2003) In a perfect ocean: the state of fisheries and ecosystems in the North Atlantic Ocean. Island Press, $175 \mathrm{pp}$

Perus J, Bonsdorff E (2004) Long-term changes in macrozoobenthos in the Åland Archipelago, northern Baltic Sea. J Sea Res 52:45-56

Piersma T. (2006) Waarom nonnetjes samen klaarkomen en andere wonderen van het wad. KNNV Uitgeverij, Utrecht, 192 pp

Piersma T, Hoekstra R, Dekinga A, Koolhaas A, Wolf P, Battley P, Wiersma P (1993) Scale and intensity of intertidal habitat use by knots Calidris canutus in the western Wadden Sea in relation to food, friends and foes. Neth J Sea Res 31:331-357

Piersma T, Koolhaas A, Dekinga A, Beukema JJ, Dekker R, Essink K (2001) Long-term indirect effects of mechanical cockle-dredging on intertidal bivalve stocks in the Wadden Sea. J Appl Ecol 38:976-990

Postma H (1957) Size frequency distribution of sands in the Dutch Wadden Sea. Arch Neerl Zool 12:319-350

Reise K (1982) Long-term changes in the macrobenthic invertebrate fauna of the Wadden Sea: are polychaetes about to take over? J Sea Res 16:29-36

Reise K (1995) Predictive ecosystem research in the Wadden Sea. Helgol Meeresunters 49:495-505 
Reise K, Herre E, Sturm M (1989) Historical changes in the benthos of the Wadden Sea around the island of Sylt in the North Sea. Helgol Meeresunters 43:417-433

Reise K, Herre E, Sturm M (2008) Mudflat biota since the 1930's: change beyond return? Helgol Mar Res 62:13-22

Riesen W, Reise K (1982) Macrozoobenthos of the subtidal Wadden Sea: revisited after 55 years. Helgol Meeresunters 35:409-423

Scheffer M, Carpenter SR (2003) Catastrophic regime shifts in ecosystems: linking theory to observation. Trends Ecol Evol 18:648656

Scheffer M, Carpenter S, Foley JA, Folke C, Walker B (2001) Catastrophic shifts in ecosystems. Nature 413:591-596

Scheffer M, Carpenter S, de Young B (2005) Cascading effects of overfishing marine systems. Trends Ecol Evol 20:579-581

Smidt ELB (1951) Animal production in the Danish Wadden Sea. Meddr Danm Fisk.-og Havunders 11:1-151

Smit CJ, Dankers N, Ens BJ, Meijboom A (1998) Birds, mussels, cockles and shellfish fishery in the Dutch Wadden Sea: how to deal with low food stocks for Eiders and Oystercatchers. Senckenb Marit 29:141-153

Swart JAA, van Andel J (2008) Rethinking the interface between ecology and society. The case of the cockle controversy in the Dutch Wadden Sea. J Appl Ecol 45:82-90

Thamdrup HM (1935) Beiträge zur ökologie der wattenfauna auf experimenteller grundlage. Meddr Danm Fisk-og Havunders (Fisk) 10(2):1-125

van Beusekom JEE (2005) A historic perspective on Wadden Sea eutrophication. Helgol Mar Res 59:45-54

van der Baan G, Blok A, Nijhoff P, Swennen K (1958) Een inleidend onderzoek naar de betrekkingen tussen wadvogels en bodemfauna. Verslag werkkamp N.J.N. Sectie vogelwerkgroep KNNV en NJN, $28 \mathrm{pp}$ van Gils JA, Piersma T, Dekinga A, Spaans B, Kraan C (2006a) Shellfish-dredging pushes a flexible avian toppredator out of a protected marine ecosystem. PLoS Biol 4:2399-2404

van Gils JA, Spaans B, Dekinga A, Piersma T (2006b) Foraging in a tidally structured environment by red Knots (Calidris canutus): ideal, but not free. Ecology 87:1189-1202

van Gils JA, Kraan C, Dekinga A, Koolhaas A, Drent J, de Goeij P, Piersma T (2009) Reversed optimality and predictive ecology: burying depth forecasts population change in a bivalve. Biol Lett $5: 5-8$

van Katwijk MM, Bos AR, de Jonge VN, Hanssen LSAM, Hermus DCR, de Jong DJ (2009) Guidelines for seagrass restoration: importance of habitat selection and donor population, spreading of risks, and ecosystem engineering effects. Mar Pol Bull 58:179-188

van Raaphorst W, de Jonge VN (2004) Reconstruction of the total N and $\mathrm{P}$ inputs from the IJsselmeer into the western Wadden Sea between 1935-1998. J Sea Res 51:109-131

Verwey J (1952) On the ecology of distributions of cockle and mussel in the Dutch Wadden Sea, their role in sedimentation and the source of their food supply. Arch Neerl Zool 10:171-239

Wolff WJ (2000) Causes of extirpations in the Wadden Sea, an estuarine area in the Netherlands. Cons Biol 14:876-885

Wolff WJ (2005) The exploitation of living resources in the Dutch Wadden Sea. Helg Mar Res 59:31-38

Zwarts L, Wanink JH (1993) How the food supply harvestable by waders in the Wadden Sea depends on the variation in energy density, body weight, biomass, burrying depth and behaviour of tidal-flat invertebrates. Neth J Sea Res 31:441-476

Zwarts L, Dubbeldam W, van den Heuvel H, van de Laar E, Menke U, Hazelhoff L, Smit CJ (2003) Bodemgesteldheid en mechanische kokkelvisserij in de Waddenzee. RIZA, Lelystad, 130 pp 